Contents list available at IJRED website

Int. Journal of Renewable Energy Development (IJRED)

Journal homepage: www.ijred.com

\title{
A Feasibility Study of Biogas Technology to Solving Peri-urban Sanitation Problems in Developing Countries. A Case for Harare, Zimbabwe
}

\author{
G. Sibandaa ${ }^{*}$, D. Musadembaa, H.C. Chihoboa and L. Zanamwe ${ }^{b}$ \\ ${ }^{a}$ Chinhoyi University of Technology, Department of Fuels \& Energy, P.Bag 7724, Chinhoyi, ZIMBABWE \\ ${ }^{b}$ University of Zimbabwe, Department of Geography \& Environmental studies, \\ P.O. Box MP 167, Mt Pleasant, Harare, ZIMBABWE
}

\section{Article history:}

Received March 21, 2013 Received in revised form April 22, 2013 Accepted April 24, 2013 Available online

\begin{abstract}
This study investigated the feasibility of converting organic waste into energy using biogas technology to address sanitation problems in peri-urban suburbs of Harare, Zimbabwe. These suburbs with an estimated population of 156.975 are unique in that they are not connected to the Harare main water sewer system. A baseline survey was conducted to determine the quantity of biodegradable human and kitchen waste $(\mathrm{N}=60)$. Biodigester sizing and costing was done for various scenarios mainly household standalone, single centralised suburb and combined suburbs centralised biogas models. In addition potential biogas conversion to electricity was done for single centralised suburb and combined suburbs centralised biogas models. This was followed by a cost benefit analysis of employing combined suburbs biogas technology. A combined suburbs centralised biogas model was found to be the most feasible scenario producing $7378 \mathrm{~m}^{3}$ of biogas per day with electricity production capacity of $384 \mathrm{~kW}$.There was a potential of wood savings of 6129 tonnes/year, paraffin savings of 2.556 tonnes/year and greenhouse benefits of 980 tonnes of $\mathrm{CO}_{2}$ equivalent emissions/ year and which would attract $\mathrm{U} \$ 2940$ from carbon credits sales per year. The study recommended the adoption of the biogas technology because of its potential to address both economic and sanitation challenges being faced by local authorities in developing countries particularly, improved hygienic conditions, energy supply chronic epidemics and sewer reticulation.
\end{abstract}

Keywords: biogas conversion, carbon credits, greenhouse gases, human waste, kitchen waste, peri-urban sanitation

\section{Introduction}

Peri-urban areas in developing countries are facing serious problems in terms of provision of adequate sanitation facilities (Achankeng 2003). They also face problems of garbage disposal and sewage treatment (Sira et al. 2001). In Zimbabwe these mounting problems have resulted in several outbreaks of water borne diseases such as cholera, dysentery and typhoid particularly in high density peri-urban suburbs of Harare. Manyukwe (2009) reported 98585 cases of cholera resulting in 4287 deaths in Harare's peri-urban suburbs. Most of the peri-urban high-density, low- income suburbs are not connected to the central water reticulation or sewer systems.

This study explored opportunities for introducing biogas technology to solve current challenges associated with waste disposal. Waste considered in this paper includes organic kitchen and human waste. In addition a cost benefit analysis of employing biogas technology was conducted for three peri-urban suburbs of Harare. A feasibility analysis employed in the study included quantification of wastes, potential gas production and energy likely to be generated from converting biogas into electricity. The intervention can provide a source of energy to peri-urban households

*Corresponding Author: +263 712 874729; fax \# +263 6723726

Email: sibandagt@gmail.com 
who are yet to be connected to the city power grid (Lohri 2009).

Study sites were Epworth, Hatcliffe Extension and Whitecliffe sampled from a list which included Hopley, Caledonia, and numerous extensions to the already established high density suburbs such as Kuwadzana, Dzivaresekwa, Budiriro and so on. Fig. 1 shows periurban suburbs in Harare and the areas understudy.

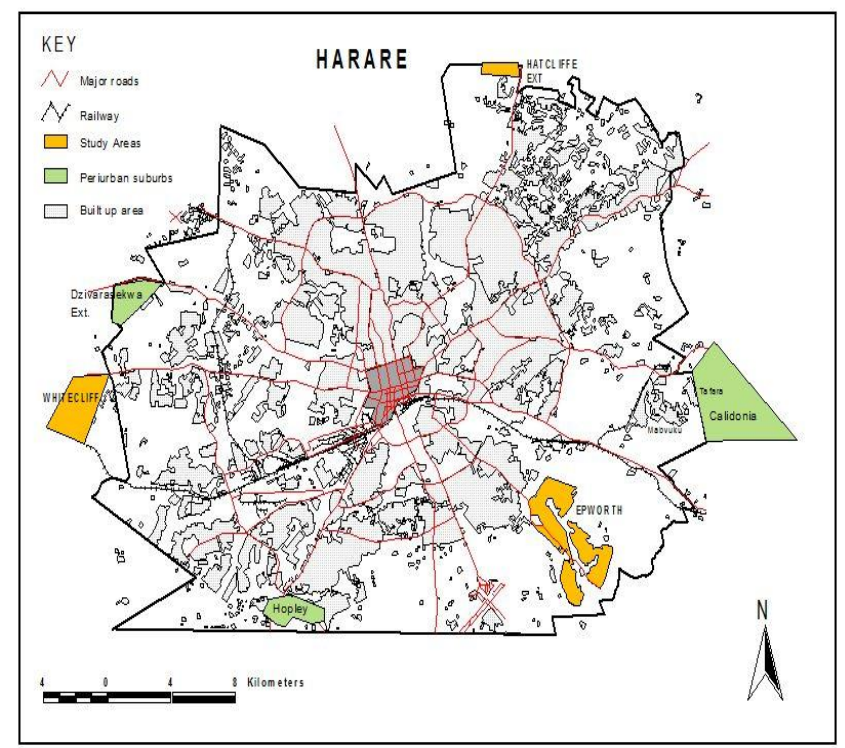

Fig. 1 Peri-urban suburbs in Harare and the areas understudy

The population of Epworth was taken as 114067 (Zimbabwe Population Census 2002). Hatcliffe and Whitecliffe populations were estimated as 23897 and 19011 respectively as accurate figures were difficult to find since these suburbs emerged after the 2002 population census. These unconnected suburbs use improperly designed pit latrines and deep wells to dispose of their human and kitchen waste. The current sizes of their stands preclude the introduction of water reticulated system in the near future. Any system to be introduced will be very expensive and may not be political or even socially acceptable. These settlements are not easy to service but might provide an investment opportunity for private business to provide services to them. However, it must be borne in mind that whatever solution will be settled upon will be likely to be expensive and might need planning in decades rather than the short term to achieve.

The study had several objectives. The first objective was to carry out a baseline survey to establish the current sources, use and expenditure of communities in the selected peri-urban areas on their daily energy consumption. The second objective sought to establish the knowledge, perceptions and attitudes of the same communities to the use of biogas as a substitute or complimentary energy source. The study went on to further investigate the quantities of biomass waste generated at household and community levels in these peri-urban areas of Harare. Using these, the study sought to carry out an economic analysis of the monetary benefits that may accrue to communities by adopting biogas technologies using various models from previous studies. It also tried to establish the environmental benefits that would accrue to the communities and the nation by adopting these technologies. Lastly we sought to recommend models for producing biogas using the economic models that applied best to the peri-urban communities and Harare at large.

\section{Materials and Methods}

\subsection{Suburbs Survey}

Purposive sampling of households was done in each of the three identified suburbs (i.e. Hatcliffe Extension, Whitecliffe and Epworth). A total of 60 questionnaires were administered of which 40 were targeted at households in the three suburbs and were 20 being administered to businesses. In actual fact, for each suburbs: 15 questionnaires were directed at households and 5 were targeted at business operating in the area. As stated above, in the objectives, the aim was to get the current status of energy use and needs in these suburbs and not to be representative. So for households the questionnaire addressed issues such as demographic characteristics, current energy mix in terms of use, awareness of biogas and its acceptability, health issues, expenditure on energy and so on. To establish the feasibility of using household waste for biogas production the questionnaire also sought to establish whether households produced sufficient quantities of these to meet the requirements to feed a biodigester.

For business, the main focus was on the economic viability of biogas as an economic adventure. Would they consider going into biogas production by transporting it to designated sites, producing it and then bottling and distributing it to consumers in the peri-urban suburbs? This question was also put to key informants in the local authorities such as Harare Water, Harare Waste and the Municipal Council i.e. the Town Engineers Office.

\subsection{Laboratory tests}

Organic samples from kitchen and human wastes (3 samples from each suburb) were collected with the aim of determining their total solid (TS) and volatile solid components (VS).

a) The total solids (TS) were determined using the convection oven method which involved heating samples of $10 \mathrm{~g}$ each of the biodegradable municipal solid waste and air dried at $105 \pm 3^{\circ} \mathrm{C}$ for three hours. The dried waste was then allowed to cool to room temperature in a desiccator after 
which it was weighed. The weight of the sample plus weighing dish was recorded. The sample was again heated in a convection oven at $105 \pm 3^{\circ} \mathrm{C}$, until a constant weight change of $\pm 0.1 \%$ change was achieved upon one hour of re-heating the sample. The TS was then calculated from the formulae

$$
T S=\frac{\text { mass of dried sample remains }}{\text { initial mass of sample }}
$$

b) The volatile solids (VS) of the substrate was determined by igniting the dried samples from (a) in a muffle furnace for two hours at $500^{\circ} \mathrm{C}$. The initial mass of the dried sample prior to ignition was recorded and the final mass of the solid remained after 2 hours of ignition was recorded. VS was then determined from the formulae

$$
V S=1-\frac{\text { mass of solid remains after igniting the sample }}{\text { initial mass of the dried sample }}
$$

\subsection{Data analysis}

The data from the questionnaires was pre-coded and captured using Excel and analysed using SPSS to produce tables and figures from survey data. Descriptive statistics were computed for the quantitative data using SPSS, while the qualitative data from the key informant interviews were deductively synthesised to identify the major themes related to the feasibility study. From this data, frequency tables and cross-tabulations were generated. The cross-tabulated data was then processed using Equations 4 to 7 . However, some of the data fed into these equations were from standard models for estimating the feasibility of producing and using biogas as an alternative energy source from household waste. The analysis also included using the equations to address issues of a technical nature in the production and use of biogas.

The researchers also estimated the size of biodigesters and carried out a cost-benefit analysis for each scenario. These included the estimation of biodigester size, technical and economic feasibility of using various biogas setups, the cost and benefits of setting them up as well as their financial viability for electricity generation. This placed the study in its proper context in terms of the objectives stated for this research.

\subsection{Estimation of the biodigester size}

To estimate the size of the biogas digesters the following equation was used:
Digester volume ( $\mathrm{Vd})$ :

$V_{d}=S_{d} \times R_{t}$

Where $S_{d}$ is daily substrate,

$R_{t}$ is retention time taken to be 25 days.

To estimate quantity of waste generated the following equation was used:

Quantity of wastes produced:

$=$ Population $x$ per capita waste generated $x$ fraction delivered to biogas plant

The fraction of total waste to be delivered to biogas plant was taken as 0.8 of which 0.2 was assumed to be utilized at source of production, burnt or uncollected (McInerney 2011). For kitchen waste $1 \mathrm{~kg}$ yields $0.1 \mathrm{~m}^{3}$ of biogas and human waste yields $0.025 \mathrm{~m}^{3}$ (Biogas Community Plants Manual GTZ). The biogas electricity generator capacity was determined by assuming that $1 \mathrm{~m}^{3}$ of biogas produces $1.25 \mathrm{kWh}$ of electricity (Alwis de 2001).

\section{Technical Economic Feasibility Assessment}

Three scenarios for biogas set-up systems were considered and these were:

- Individual household biogas digester units,

- Single centralized biogas digester unit for Epworth ward as representative of other suburbs under study.

- Combined suburbs centralized biogas digester unit for all suburbs under study

For the combined suburbs centralized biogas digester model Hatcliffe Extension was chosen as the location of the biodigester because there exists an area reserved for this purpose by the City of Harare.

The economic feasibility assessments were based on the design of fixed dome digesters that could last for 40 years depending on the quality of construction and the materials used and appropriate biogas electricity generator. However, the economic life of a plant was taken as 15 years mainly because any cost or benefit accrued after 15 years will have increased less value and hardly influenced the value of the Internal Rate of Return (IRR) (University of Zimbabwe study guide).

\section{Cost}

The capital costs for biodigester construction were estimated by considering costs of existing technological facilities in Zimbabwe and were estimated to be $\$ 150$ $/ \mathrm{m}^{3}$ (University of Zimbabwe Renewable Energy Study Guide).In Rwanda and South Africa the price of constructing digesters is estimated at $\$ 140 / \mathrm{m}^{3}$ and 
$\$ 185 / \mathrm{m}^{3}$ respectively (SNV Uganda 2008). The operating and maintenance costs were estimated at $\$ 10 /$ year $/ \mathrm{m}^{3}$ considering costs of labour, maintenance, repairs, insurance and contingency costs (EuropeanAsian Energy Facility $\{\mathrm{EAEF}\}$ Guideline 2006). The cost of generator to convert biogas to electricity was estimated at $\$ 100$ per $\mathrm{kW}$ with a life span of 5 years. In this case a new generator is purchased at the end of the life span hence the present values for the costs of generators were taken into consideration. Maintenance costs were taken to be $10 \%$ of the generator investment costs. These sets of data allowed the bio-digester and biogas electricity generator capital pay-back periods to be estimated along with other economic indicators such as net present value and internal rate of returns and other annual revenue streams.

\section{Benefits}

The benefits of biogas included avoided cost of purchasing alternative fuels (wood and kerosene) and fertiliser. To calculate benefits of using biogas $1 \mathrm{~m}^{3}$ of biogas was equated to $1.3 \mathrm{~kg}$ of wood or $0.5 \mathrm{~kg}$ of kerosene (Rojorhia et al. undated). The fertilizer produced was estimated as $20 \%$ of initial feedstock (Biogas community plants manual). The price of fertilizer was estimated from the cost of compound D fertilizer in Zimbabwe which was US\$0.60/kg. Periurban households use fertilizers in their lands even though there is suppressed demand due the high costs. A metric tonnes of $\mathrm{CO}_{2}$ was estimated at an average price of US\$3 in developing countries and 1 tonnes of $\mathrm{CO}_{2}$ equivalent was equated to 1 credit unit (Mark undated). Fertilizer from digested slurry was pegged as $\$ 0.60 / \mathrm{kg}$ while electricity sales $/ \mathrm{kWh}$ were $\$ 0.16$ the price of electricity in Zimbabwe. About $0.473 \mathrm{~kg}$ of $\mathrm{CO}_{2}$ equivalent emissions would be saved annually per household (Bajracharga 2010). Time savings based on reduced time to collect/buy fuel wood, cooking food and decreased health costs were not considered as households did not perceive the saved time as a financial benefit.

\section{Financial viability of biogas plants and electricity generation}

The financial viability of biogas plants depended on whether output in the form of gas and slurry can Tabel 1 Distribution of the respondents by sex and residential suburb

\begin{tabular}{|c|c|c|c|c|c|c|}
\hline \multirow{3}{*}{ Suburb } & \multicolumn{6}{|c|}{ Sex of respondent } \\
\hline & \multicolumn{2}{|c|}{ Female } & \multicolumn{2}{|c|}{ Male } & \multicolumn{2}{|c|}{ Total } \\
\hline & Number & Percent & Number & Percent & Number & Percent \\
\hline Hatcliffe Extension & 7 & 18.0 & 6 & 15.0 & 13 & 33.0 \\
\hline Whitecliffe & 10 & 25.0 & 7 & 18.0 & 19 & 43.0 \\
\hline Epworth Ward & 3 & 8.0 & 6 & 15.0 & 9 & 23.0 \\
\hline Total & 21 & 52.0 & 19 & 48.0 & 40 & 100.0 \\
\hline
\end{tabular}

substitute for fuels, fertilizers or feeds which were purchased with money by respondents. The resulting cash savings could be used to repay the capital and operational and maintenance costs and the plants could have a good chance of being financially viable. If the output did not generate a cash inflow, or reduce cash outflow, then plants lose financial viability.

Economic evaluation of biogas production and subsequent electricity generation was therefore done based on:

$$
\begin{aligned}
& N P V=-I_{0}+\sum_{1}^{n} \frac{B-C}{1+r^{2}} \\
& t_{P B}=\frac{-\operatorname{In}\left(1-\frac{I_{0} r}{C F}\right)}{\operatorname{In}(1+r)}
\end{aligned}
$$

$$
I R R=\gamma_{1}+\frac{\left(r_{2}-r_{1}\right)\left(N P V_{1}\right)}{N P V_{2}+N P V_{1}}
$$

where:

- $\quad \mathrm{NPV}$ is the net present value,

- $t_{P B}$ is dynamic payback period,

- IRR is the internal rate of return,

- $\mathrm{I}_{0}$ is the initial investment,

- B represents the benefits in the project life,

- $\mathrm{r}$ is the interest rate (assumed to be $10 \%$ ), and

- $\quad$ C represents the costs.

Biogas price was taken as the average daily household expenditure on sources of energy. Prices greater than this value were taken as a cost to households.

\section{Results and Discussions}

\subsection{Socio-economic characteristics of the respondents}

The respondents from the study areas constituted $52.5 \%$ females and $47.5 \%$ were males. This distribution approximates the national sex representation and therefore gives a level of confidence to the findings from the study. Table 1 gives the distribution of the respondents by sex and residential suburb.

Source: Survey data

Note: Numbers might not add up to $100 \%$ due to rounding. 
Most of the respondents had low income of less that USD 200 per month. Thirty-one percent of respondents in the three suburbs fell into this category with the majority being found in Epworth. The reason for the low levels of income is because most of the respondents were self-employed i.e. they were mainly informal sector traders. Most respondents lived in households of between 2-4 persons. This agrees with Harare's average household size of 4 persons from the 2002 Population census. This means most households are composed of spouses and their children. Most of the children are below the age of 15 years, meaning they are mostly of school going age. This might have implications for involving schools in waste management and energy production.

\subsection{Energy sources used per suburb}

Figure 2 presents an aggregated view of energy use in the three suburbs. It can be deduced that wood and paraffin are the main energy sources used in these suburbs. Gas was not used in any of the suburbs.

The distribution of energy used in each suburb is given in Table 2 . Whitecliffe being the most recently established suburb seems to rely exclusively on wood and paraffin to meet its heating and cooking needs.

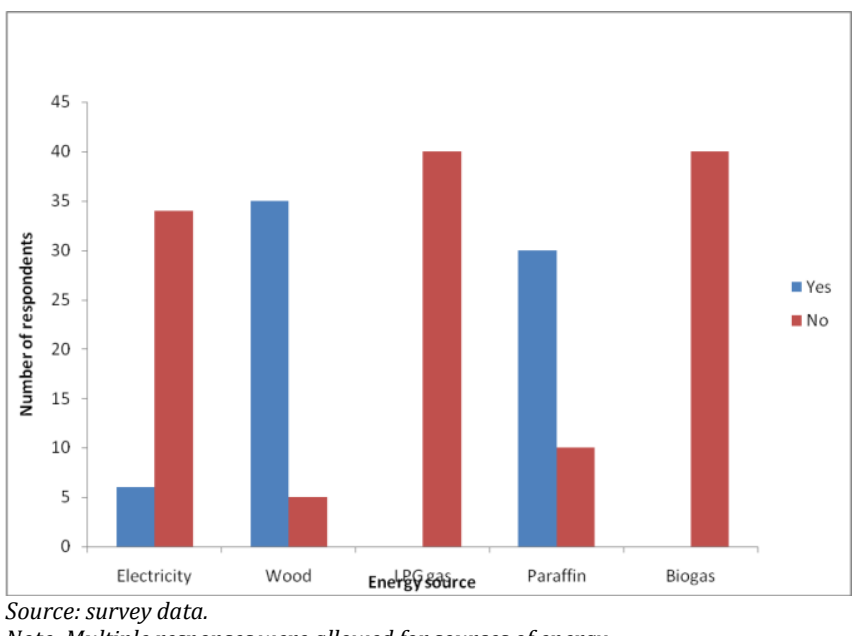

Note: Multiple responses were allowed for sources of energy

Fig. 2 Energy sources used in the three suburbs.

Tabel 2

Energy use by suburb

\begin{tabular}{lccc}
\hline \multirow{1}{*}{ Suburb } & \multicolumn{3}{c}{$\begin{array}{c}\text { Energy source (number of } \\
\text { respondents; multiple responses } \\
\text { allowed }\end{array}$} \\
\cline { 2 - 4 } & Electricity & Wood & Paraffin \\
\hline Hatcliffe Extension & 2 & 13 & 8 \\
Whitecliffe & 3 & 17 & 13 \\
Epworth & 1 & 5 & 9 \\
\hline
\end{tabular}

Source: survey data
Paraffin is versatile in providing both heat for cooking and lighting compared to wood which is mainly used for cooking by respondents. The survey therefore gives evidence of energy poverty by respondents as they try to meet their energy needs. The wood is scarce but it is the most widely used resource. This is worsened by lack of modern energy supply services such as connection to electricity; deplorable living conditions which are characterised by absence of proper latrines and open waste disposal methods leading to disease outbreaks.

\subsection{Households energy expenditure}

For the respondents who use electricity for various purposes about $10 \%$ of them paid US\$ $21-40$ in monthly bills. About $50 \%$ of the respondents spent between US $\$ 11-40$ on wood and $65 \%$ spent between US\$1-20 on paraffin per month. This gives a daily average household energy expenditure of US\$0-40. It would seem most households will be able to pay for biogas and biodigester maintenance from the savings of buying wood and paraffin but this depends on the price visa vies cost.

\subsection{Household energy consumption}

Most respondents indicated that they consumed wood for 2-3 hours for cooking purposes. This was compared to less than 1 hour when paraffin was used for the same purpose. Heating about 2 litres of water using wood was generally observed to take slightly less than 1 hour. This probably indicates that the technology used for cooking with wood is less efficient when compared to the use of paraffin stoves. It might also reflect the relative cost of each source of energy for the various purposes as discussed above.

\section{Health impacts perceptions of energy use}

The study also sought to establish the perceptions of respondents on the use of various energy sources. The questions did not restrict itself to the current energy used but asked in general terms for opinions on various sources including gas. Table 3 summarizes some of the perceptions of the respondents on the impacts to health of various energy sources.

About 33\% of the respondents associated wood and paraffin with breathing problems. Wood and gas were also perceived as being potentially dangerous because of their ability to cause accidental fires. Thus any attempts to introduce biogas should be accompanied by intensive awareness campaigns about the safety use of the fuel. 
Citation: Sibanda, G., Musademba, D., Chihobo, H.C. \& Zanamwe, L. (2013) A Feasibility Study of Biogas Technology to Solving Peri-urban Sanitation Problems in Developing Countries. A Case for Harare, Zimbabwe. Int. Journal of Renewable Energy Development, 2(2), 97-104

P a g e $1 \mathbf{1 0 2}$

Tabel 3

Perception of health impact of various energy sources by households

\begin{tabular}{|c|c|c|c|c|c|c|}
\hline \multirow{3}{*}{ Perceived health impact } & \multicolumn{6}{|c|}{ Energy Source } \\
\hline & \multicolumn{2}{|c|}{ Wood } & \multicolumn{2}{|c|}{ Paraffin } & \multicolumn{2}{|c|}{ Biogas/LPG gas } \\
\hline & Number & Percent & Number & Percent & Number & Percent \\
\hline Coughing & 2 & 5.0 & 2 & 5.0 & 1 & 2.5 \\
\hline Respiratory & 13 & 32.5 & 12 & 30.0 & 3 & 7.5 \\
\hline Chest pains & 2 & 5.0 & 2 & 5.0 & - & -0 \\
\hline Accidental fires & 2 & 5.0 & - & - & 3 & 4.5 \\
\hline Headache & - & - & 2 & - & - & - \\
\hline
\end{tabular}

Source: survey data

Note: '-'figures were too small to be significant.

\section{Respondents awareness of biogas technology}

The results in terms of awareness or knowledge of biogas are presented in Table 4. Knowledge of biogas is fairly low in all three suburbs with only $40 \%$ of all respondents being aware of it. This means the introduction of biogas will need massive awareness campaigns.

It was established that most respondents (82\%) would not have problems with the use of human wastes for generating fuel for cooking. Those who indicated problems related use of human waste to generate fuel for cooking as associated with spread of diseases that could affect human health. The respondents could not provide evidence of the spread of such diseases.

Tabel 4

Household awareness of biogas technology by suburb

\begin{tabular}{lcccc}
\hline \multirow{2}{*}{ Suburb } & \multicolumn{3}{c}{ Household awareness of biogas technology } \\
\cline { 2 - 5 } & \multicolumn{3}{c}{ Yes } & \multicolumn{2}{c}{ No } \\
\cline { 2 - 5 } & Number & Percent & Number & Percent \\
\hline Hatcliffe & 5 & 12.5 & 8 & 20.0 \\
Extension & & & & \\
Whitecliffe & 7 & 17.5 & 11 & 27.5 \\
Epworth & 4 & 10.0 & 5 & 15.5 \\
Total & $\mathbf{1 6}$ & $\mathbf{4 0 . 0}$ & $\mathbf{2 4}$ & $\mathbf{6 0 . 0}$ \\
\hline
\end{tabular}

Source: survey data

\section{Laboratory tests results}

The findings from laboratory experiments carried out to determine solid content of kitchen and human waste are as shown in Table 5.

Tabel 5

Characteristics of substrate for Total Solids (TS) and Volatile Solids (VS)

\begin{tabular}{lcc}
\hline Substrate & TS\% & VS\% \\
\hline Kitchen waste & 9 & 80 \\
Human waste & 5 & 75 \\
\hline
\end{tabular}

A large fraction of this waste is biodegradable thus it can be used as a feedstock for methane production. The low percentage of total solids (TS) is due to the composition of food waste, sadza (thick porridge) vegetables, fruit remains and peels which had high moisture content (MC). The high percentage of the volatile solids (VS) $75 \%$ to $80 \%$ indicates the organic portion of the feedstock, which characterizes the digester systems input feedstock when expressed as a fraction of total sample (wet) weight. City of San Rafael Sanitation Agency (2008) indicated that VS contents of $70 \%$ and above make solid wastes biodegradable. It must be noted that when sadza (thick porridge from maize meal or soghum) is used as main feedstock to the digester, it tends to become more acidic with increased retention time. Research has shown that this inhibits the activities of methane producing bacteria. Introduction of chemicals to neutralise the acidity will therefore be recommended.

\section{Household stand alone biogas model}

The survey carried out established that the daily kitchen waste produced per household with an average number of 4 people was $1.1 \mathrm{~kg} /$ day which translates to $0.0275 \mathrm{~kg} /$ person/day. This per capita waste generation is consistent with the daily per capita waste generation in low income countries. The total biodegradable waste i.e. human and kitchen does not add up to $5 \mathrm{~kg}$ the recommended minimum economic input of waste material for a household standalone biodigester to meet daily lighting and heating needs (Lonhri 2009). This means a household standalone biogas model is not feasible. Collection of wastes to a single central location can therefore be envisaged as a feasible option.

\section{Single suburb centralised biogas model for an Epworth Ward}

Table 6 shows potential waste production, gas yield and electrical power generation for a single ward in Epworth with 4752 households.

Tabel 6

Potential waste production, gas yield and electrical power generation for a single suburb centralized biodigester in Epworth ward

\begin{tabular}{llll}
\hline & Kitchen waste & Human waste & $\begin{array}{c}\text { Combined } \\
\text { kitchen \& } \\
\text { human waste }\end{array}$ \\
\hline Total waste & $5228 \mathrm{~kg} /$ day & $7604 \mathrm{~kg} /$ day & $12832 \mathrm{~kg} /$ day \\
Biogas yield & $418 \mathrm{~m}^{3} /$ day & $475 \mathrm{~m}^{3} /$ day & $894 \mathrm{~m}^{3} /$ day \\
Power & $22 \mathrm{~kW}$ & $24 \mathrm{~kW}$ & $46 \mathrm{~kW}$ \\
\hline
\end{tabular}


Total wastes (kitchen and human) have a potential of producing at least $475 \mathrm{~m}^{3}$ /day of biogas. About 687 households would benefit from the biogas production for use in cooking and lighting. According to Bajracharya (2010) $1 \mathrm{~kg}$ of fuel wood is equal to $438 \mathrm{~g}$ of $\mathrm{CO}_{2}$ equivalent emissions. This translates to $325 \mathrm{~kg}$ of $\mathrm{CO}_{2}$ equivalent emissions that would be saved annually for the 687 households with full replacement of fuel wood. The emissions saved would only attract 0.325 carbon credits.The biogas produced would translate to $24 \mathrm{~kW}$ of electricity per day. With these figures commercial production of biogas is viable at modest level.

\section{Combined suburbs centralised biogas model for the three suburbs}

Table 7 shows potential waste and biogas production and respective electricity generation potential for combined suburbs centralised biogas model for Hatcliffe Extension, Whitecliffe and a ward in Epworth.

There is more biogas production potential $(7378 \mathrm{~m} 3$ /day) in a combined suburb centralised biogas model. This gas has a capacity of producing about $384 \mathrm{~kW}$. Other potential annual benefits accrued from single suburb and combined suburbs centralised biogas models are summarised in Table 8.

The financial viability of biogas plants depends on economies of scale which tend to make them a better prospect financially. Benefits from a combined suburbs

Tabel 7

Potential waste production, gas yield and electrical power generation for combined suburbs centralized biogas model for Hatcliffe Extension, Whitecliffe and an Epworth ward

\begin{tabular}{llll}
\hline & $\begin{array}{l}\text { Kitchen } \\
\text { waste }\end{array}$ & $\begin{array}{l}\text { Human } \\
\text { waste }\end{array}$ & $\begin{array}{l}\text { Combined } \\
\text { kitchen \& } \\
\text { human waste }\end{array}$ \\
\hline $\begin{array}{l}\text { Total waste } \\
\text { (kg/day) }\end{array}$ & 43168 & 62790 & 105958 \\
$\begin{array}{l}\text { Gas yield(m }{ }^{3} / \text { day) } \\
\text { Power(kW/day) }\end{array}$ & 3453 & 3924 & 7378 \\
& 180 & 204 & 384 \\
\hline
\end{tabular}

Tabel 8

Potential benefits accrued from single suburbs and combined suburbs biogas units

\begin{tabular}{lcc}
\hline Benefits & $\begin{array}{c}\text { Single } \\
\text { suburbs } \\
\text { centralised } \\
\text { biogas unit }\end{array}$ & $\begin{array}{c}\text { Combined } \\
\text { suburbs } \\
\text { centralised } \\
\text { biogas unit }\end{array}$ \\
\hline $\begin{array}{l}\text { Wood savings(tonne/year) } \\
\text { Paraffin savings(tonne/year) }\end{array}$ & 325 & 6129 \\
$\begin{array}{l}\text { Greenhouse(tonne of } \quad \mathrm{CO}_{2} \\
\text { equivalent/year) }\end{array}$ & 118 & 2.55 \\
$\begin{array}{l}\text { Carbon credits earnings(\$/year) } \\
\begin{array}{l}\text { Number of households to benefit } \\
\text { from biogas cooking and lighting }\end{array}\end{array}$ & 354 & 980 \\
\hline
\end{tabular}

centralised biogas unit can be shared by poorer households that would not be able to afford the investment and operating and maintenance costs of individual household biogas units. The quantity of benefits thus increases as amount of waste accumulates with increasing number of suburbs.

\section{Economic feasibility of proposed biogas units}

Table 9 shows the results of economic evaluation of biogas production from total wastes combined based on financial calculations. Estimated size of biodigester used in the costing is $5297 \mathrm{~m}^{3}$.

Tabel 9

Economic evaluation of biogas production from total wastes from the three suburbs combined based on a discount rate of $10 \%$

\begin{tabular}{|c|c|c|c|}
\hline Description & $\begin{array}{c}\text { Costs } \\
\text { US } \$\end{array}$ & Description & $\begin{array}{c}\text { Benefit } \\
\text { US } \$\end{array}$ \\
\hline $\begin{array}{l}\text { Io (3 } 218 \mathrm{~m}^{3} \\
\text { bio-digester } \\
\text { investment) }\end{array}$ & 794685.90 & $\begin{array}{l}\text { Fertilizer } \\
\text { Revenue/year }\end{array}$ & 152579.70 \\
\hline $0 \& \mathrm{M}$ & 52979.06 & $\begin{array}{l}\text { Biogas } \\
\text { sales/year }\end{array}$ & 35413.56 \\
\hline Transport/year & 7946.86 & $\begin{array}{l}\text { Carbon credit } \\
\text { sales /year } \\
\text { Annual cash } \\
\text { flow }\end{array}$ & $\begin{array}{l}2940.00 \\
130007.30\end{array}$ \\
\hline $\begin{array}{l}\text { NPV- \$194160, } \\
20\end{array}$ & $\begin{array}{l}\text { payback } \\
\text { period- } \\
6 y e a r s\end{array}$ & IRR-15\% & \\
\hline
\end{tabular}

\section{Tabel 10}

Economic evaluation of electricity generation from biogas production from combined suburbs centralised biodigester based on discount rate of $10 \%$

\begin{tabular}{|c|c|c|c|}
\hline Description & $\begin{array}{c}\text { Costs } \\
\text { US } \$\end{array}$ & Description & $\begin{array}{c}\text { Benefit } \\
\text { US \$ }\end{array}$ \\
\hline $\begin{array}{l}\mathrm{Io}\left(5297 \mathrm{~m}^{3} \text { bio- }\right. \\
\text { digester + } 400 \\
\mathrm{~kW} \text { Generator } \\
\text { investment }) \text { assu } \\
\text { ming generator } \\
\text { costsUS75/kw }\end{array}$ & 826237.46 & $\begin{array}{l}\text { Fertilizer } \\
\text { Revenue/year }\end{array}$ & 152579.70 \\
\hline $\begin{array}{l}\text { 0\&M for system } \\
\text { (digester and } \\
\text { engine) }\end{array}$ & 56829.12 & $\begin{array}{l}\text { Electricity } \\
\text { sales/year }\end{array}$ & 56064 \\
\hline $\begin{array}{l}\text { Transport } \\
\text { costs/year }\end{array}$ & 7946.86 & $\begin{array}{l}\text { Carbon credits } \\
\text { sales / year }\end{array}$ & 2940.00 \\
\hline NPV- $\$ 53707.24$ & $\begin{array}{l}\text { payback } \\
\text { period- } \\
7 y e a r s\end{array}$ & $\begin{array}{l}\text { Annual cash } \\
\text { flow } \\
\text { IRR } \%-10.5 \%\end{array}$ & 146807.72 \\
\hline
\end{tabular}

The payback period is 6 years and the IRR is $15 \%$. The EAEF guidelines (2006) indicate that bigger biodigesters have payback periods of 5 years and above. This is supported by SNV Uganda(2008) in S.A National Household Biogas Feasibility report (2008) that big community biodigesters have payback periods of 5 to 7 
years. Also the IRR is greater than $10 \%$, the discount rate used in the study which makes the project viable.

Table 10 shows the economic evaluation of converting biogas to electricity. The NPV is greater than zero and the IRR is greater than $10 \%$ with a short payback period of 7 years making the combined suburbs centralised biogas electricity model a viable option.

\section{Conclusion}

It can be concluded that apart from the poor sanitation status of the peri-urban suburbs of Harare, the residence are faced with a challenge fuel provision. The most prevalent source of fuel used is wood which is scarce. The residence indicated willingness to switch over to biogas if the technology is availed to them. Biogas technology has the potential to provide numerous environmental and socioeconomic benefits, such as reduced sanitation problems, reduced rates of deforestation and improved indoor air quality in periurban suburbs of developing countries.

The study also indicated that for these peri-urban areas, the standalone household biogas model is not economically feasible due low production quantities of kitchen and human waste. Therefore, it can be concluded that the combined suburbs centralised biogas model is the most economically feasible option. The model has the potential to produce $7378 \mathrm{~m}^{3}$ of biogas/day with electricity production capacity of $384 \mathrm{~kW}$. With this model, a potential of wood saving of 6129 tonnes/year, paraffin savings of 2.556 tonnes/year and greenhouse benefit of 980 tonnes of $\mathrm{CO}_{2}$ equivalent emissions/year that would attract US $\$ 2940$ from carbon credit sales per year were observed.

\section{Recomendations}

In view of the findings the following recommendations can be made:

- Combined suburbs centralized biodigester be adopted for all peri-urban suburbs not connected to main sewer lines in Harare and other urban local authorities in Zimbabwe.

- There is a need for a vigorous campaign to get local authorities in Zimbabwe to realize the utility of biogas generation as a waste and sanitation reduction management tool as well as an alternative source of electricity generation

- The use of biogas technologies be adopted by Harare and other local authorities for the beneficial impacts it will have on the health of populations in their peri-urban settlements

- Given the low level of biogas knowledge by respondents, education, training and awareness campaigns should be carried out both in Harare and other urban local authorities in Zimbabwe to encourage the adoption and use of biogas technologies.

- There is a need to engage business people/investors and provide them with skills so that they invest in biogas generation on a commercial basis.

\section{References}

Achankeng, E. (2003) Globalisation, Urbanisation and Municipality Solid Waste management in Africa. Proceedings of the African studies Association of Australasia and the Pacific, Africa on a Global Scale.

Alwis, A. de. (2001) Study on the potential for biogas in Sri Lanka. ITDG South Asia.

Amigun, B. \& von Blottnitz, H. (2007) Investigation of scale economies for African biogas field study. Solar Energy, 82(4), 911-917.

Bajracharya, L. (2010) Assessment of Improved Cooking Stove (ICS) in Firewood Consumptions and Reducing Carbon Dioxide Emission: A Case Study from TMJArea, Nepal. International Program on Research and Training on Sustainable Management of Mountain areas.

City of San Rafael Sanitation Agency (2008) Methane Capture Feasibility Report

EC- Asian Energy Facility Programme Guideline (EAEF). (2005) Overview of Policy Instruments for the Promotion of Renewable Energy Efficiency in Asian Member countries report, www.s3.amazonaws.com/zanran storage/www.serd.ait.ac.th/.../ 12639875.pdf Accessed on 25 March 2012.

Government of Zimbabwe (2004) Census 2002. National Report, Central Statistical Office, Harare

GTZ (undated) Biogas Community Plants Manual.

Lohri and Christian (2009) Research on Anaerobic Digestion of Solid Waste on Household Level in Dar es Salaam, Tanzania. Zurich University of Applied Sciences.

Manyukwe, C. (2009) Disease outbreaks plague Zimbabwe, The Herald, Harare

Mark, J. (undated) Climate change, http://www.climate-changewisdom.com/carbon-trading.html. Accessed on 28 April 2012

McInerney Peter, J. (2011) Biogas Technology on Uzi Island. A Feasibility Study Zanzibar.

Rajorhia, U., Kumar, A., \& Sharma, R. (undated) Utilisation of Farm Waste in Biogas Production. http://www.landmarkgoc.com/biogas project.html. Accessed on 3 March 2012

Schmitz, Thomas, D. (2007) Feasibility Study for a National Domestic Biogas Programme inTanzania. Deutsche Gesellschaft für Technische Zusammenarbeit. Eschborn.

Sira, F.N., Thumbi, G.M., Bwisa, H.M. \& Oyugi, L.A. (2001) Sustainable Management of Domestic Solid Waste in Developing Countries: Operations, Environmental Concern and Community Based Strategies in Kenya. Journal of Civil Engineering, 6: 13-26

SNV Uganda (2008) S.A National Household Biogas Feasibility report University of Zimbabwe Renewable Energy Study Guide. 